\title{
Schistosoma mansoni Infection Is Impacted by Malnutrition
}

\author{
Poliane Silva Maciel1', Ricardo Gonçalves ${ }^{2}$, Lis Ribeiro do Valle Antonelli' ${ }^{1}$ and \\ Cristina Toscano Fonseca ${ }^{1 *}$
}

\footnotetext{
'Laboratório de Biologia e Imunologia de Doenças Infecciosas e Parasitárias, Instituto René Rachou, Fundação Oswaldo Cruz, Belo Horizonte, Brazil, ${ }^{2}$ Laboratório de Biologia de Monócitos e Macrófagos, Departamento de Patologia Geral, Instituto de Ciências Biológicas, Universidade Federal de Minas Gerais, Belo Horizonte, Brazil
}

OPEN ACCESS

Edited by: George Grant, University of Aberdeen, United Kingdom

Reviewed by: Samar Nagah El-Beshbishi, Mansoura University, Egypt Bart Everts, Leiden University Medical Center, Netherlands

*Correspondence: Cristina Toscano Fonseca cristina.toscano@fiocruz.br

Specialty section: This article was submitted to Infectious Diseases,

a section of the journal

Frontiers in Microbiology

Received: 30 November 2020

Accepted: 17 February 2021

Published: 19 March 2021

Citation:

Maciel PS, Gonçalves $R$ Antonelli $L R d V$ and Fonseca $C T$ (2021) Schistosoma mansoni Infection Is Impacted by Malnutrition.

Front. Microbiol. 12:635843. doi: 10.3389/fmicb.2021.635843
Schistosomiasis remains one of the most important neglected tropical diseases in the world. It mainly affects developing countries, where it often coexists with malnutrition. Despite this, few studies have investigated the relationship between schistosomiasis and malnutrition. Herein, we evaluate the impact of malnutrition on experimental S. mansoni infection. Mice were divided into 5 groups: Control (Ctrl) diet (14\% protein and 10\% lipids), low-protein 3\% (LP 3\%), low-protein 8\% (LP 8\%), low-fat 2.5\% (LF 2.5\%), and low-fat 5\% (LF 5\%). Mice were fed with their respective diets and were infected when a difference of approximately $20 \%$ in the body weight between mice from any experimental group and mice from the control group was achieved. Nutritional, parasitological, and immunological parameters were assessed either just before infection and/or approximately 50 days later before mice were perfused. Our results showed that the $3 \%$ low-protein diet was the only one capable of establishing malnutrition in mice. Mice fed with this diet showed: (i) significant reduction in body weight and serum albumin levels before infection, (ii) decreased levels of all biochemical parameters evaluated before perfusion, (iii) decreased numbers of schistosome eggs trapped in intestines and impaired parasite fecundity, (iv) a delay in the granuloma development with a smaller granuloma area, and (v) reduced levels of IL-4 and IFN- $\gamma$ in the liver. Our findings demonstrate that low protein supply leads to malnutrition in mice and impacts the cytokine milieu in the liver and granuloma formation. Additionally, the establishment of our murine malnutrition model will enable future studies aiming to better understand the complex relationships between nutrition, immune responses, and infection outcome.

Keywords: schistosomiasis, S. mansoni, malnutrition, low-protein diet, low-fat diet

\section{INTRODUCTION}

Schistosomiasis is a neglected tropical disease caused by parasites of the genus Schistosoma that remains as a major public health problem worldwide, being considered a disease of poverty (Ross et al., 2002; Gryseels et al., 2006; Colley et al., 2014; McManus et al., 2018). Approximately 800 million people are at risk of infection and 250 million are affected with schistosomiasis in 78 countries around the world, especially in the Middle East, South America, Southeast Asia and subSaharan Africa (WHO, 2020). The disease results in considerable human morbidity and mortality, 
notably in sub-Saharan Africa where more than $90 \%$ of all infections occur. The Global Burden of Disease (GBD) study of 2016 attributed 1.9 million disability-adjusted life years (DALYs) due to schistosomiasis (Gbd 2016 DALYs Collaborators, 2017).

Similar to schistosomiasis, malnutrition remains an important public health problem in developing countries. Protein energy malnutrition is the most frequent form of malnutrition, and globally affects 820 million people, including over 150 million children under 5 years of age, mainly in developing countries (FAO, 2019). Malnutrition is considered to be an important cause of immunodeficiency, predisposing the malnourished to a variety of different infectious diseases (Katona and Katona-Apte, 2008; Rodriguez-Morales et al., 2016). While malnutrition increases susceptibility to infection, infections aggravate malnutrition by decreasing appetite and increasing demand for nutrients, causing a vicious cycle (Katona and Katona-Apte, 2008; Bapat et al., 2015).

Malnutrition and intestinal parasitism share a similar geographic distribution, with individuals possibly experiencing both conditions. Thereby, schistosomiasis is commonly found where malnutrition is also prevalent (Coutinho et al., 1997; Atinmo et al., 2009; Barros et al., 2014; Mekonnen et al., 2014; Papier et al., 2014). Although there is evidence that malnutrition is one of the major factors influencing the outcome of schistosomiasis and vice versa, few studies have assessed the relationship between both conditions (Magalhães et al., 1986; Stephenson, 1994; Parraga et al., 1996; Coutinho et al., 1997, 2010; Barros et al., 2014).

In this context, the use of laboratory animals has been employed to understand how different degrees of malnutrition affect the host immune response, the susceptibility to infections, and pathogenesis (Borelli et al., 2007; Komatsu et al., 2007; Fock et al., 2008; Malafaia et al., 2009; Taylor et al., 2013). Most experimental models of malnutrition are limited to protein restriction (2-8\% protein) (Anstead et al., 2001; Fock et al., 2007; Malafaia et al., 2009). Furthermore, in the case of schistosomiasis, there are no studies using the diet formulation proposed by the American Institute of Nutrition (AIN) (Reeves et al., 1993), a widely used diet in experimental nutrition studies (Borelli et al., 2007; Komatsu et al., 2007; Fock et al., 2008; Malafaia et al., 2009; Taylor et al., 2013). The use of this formulation attempts to standardize the food offered to animals in order to ensure reproducibility of biological research (Reeves et al., 1993; Pellizzon, 2016). Moreover, there are no studies that evaluate the effects of a low-fat diet on S. mansoni infection, an important macronutrient that the parasite depends on from its host (Meyer et al., 1970).

In this work, we used a murine model to address the impact of malnutrition on S. mansoni infection. We evaluated the impact of two isocaloric diets supplying distinct levels of protein, and two diets supplying distinct levels of lipids, on the infection of C57BL/6 mice with S. mansoni. Our findings demonstrate that only the $3 \%$ low protein diet altered S. mansoni infection. Mice that received this diet showed reduced liver pathology with smaller granuloma size, a delay in granuloma development, and a reduced number of schistosome eggs trapped in the intestine, reflecting a reduction in parasite fecundity. Distinct from the other groups, infection in LP 3\%fed mice did not increase the levels of TNF, which may be associated with the changes observed in liver pathology in this experimental group.

\section{MATERIALS AND METHODS}

\section{Mice and Diets}

Female C57BL/6 mice (7-8 weeks old) were obtained from the Institute René Rachou (IRR)/FIOCRUZ (Fundação Oswaldo Cruz) animal facility. After weaning, mice were fed with the commercial diet CR1 (Nuvilab ${ }^{\circledR}$, São Paulo, Brazil) until the beginning of the experiments. Mice were divided into 5 groups (12 animals/group) fed with the following experimental diets (Prag Soluções Biociências ${ }^{\circledR}$, São Paulo, Brazil): Control (Ctrl): the standard diet AIN-93M (Reeves et al., 1993), containing 14 and $10 \%$ of protein and lipids, respectively; Low-protein (LP) 3 and $8 \%$ : a modified AIN-93M diet containing 3 or $8 \%$ protein, respectively; Low-fat (LF) 2.5 and 5\%: a modified AIN-93M diet containing 2.5 or $5 \%$ lipids, respectively. All diets were isocaloric. The control and low-protein diets were identical, except that the casein removed from each of the formulations of the two lowprotein diets was substituted by the same mass of corn starch. The soy oil removed from the low-fat diets was also replaced by corn starch. The energy value of both types of restricted diet (i.e., lowprotein and low-fat) was slightly lower than that of the control diet. The daily food and protein consumption was determined by weighting the diets once a week. Mice body weights were assessed 3 times per week. Sample size calculation was performed using a $90 \%$ test power, a significance level of $0.05 \%$, a standard deviation of 30 and a $40 \%$ expected difference between groups. All procedures on mice were authorized by the Ethics Committee of Animal Use of FIOCRUZ (LW2/18).

\section{Experimental Infection}

A difference of $20 \%$ in the body weight between any experimental group and the control group was used to determine the time of the infection. Schistosoma mansoni LE strain cercariae were obtained by exposing infected Biomphalaria glabrata snails to light for 1-2 $\mathrm{h}$ to induce shedding. The mice were challenged through percutaneous exposure of shaved abdominal skin for $1 \mathrm{~h}$ to water containing approximately 100 cercariae according to Smithers and Terry (1965).

\section{Worm Burden Recovery and Number of Eggs in Gut and Liver}

Mice were euthanized 50 days after infection and perfusion was performed to collect adult worms from the mesentery and liver as described by Pellegrino and Siqueira (1956). Intestine and liver were then harvested, weighed and digested with $10 \% \mathrm{KOH}$ overnight at room temperature. The eggs were resuspended in $1 \mathrm{~mL}$ of saline after centrifugation at $900 \mathrm{~g}$ for $10 \mathrm{~min}$. Three aliquots of $10 \mathrm{uL}$ each from the suspension containing the parasite eggs was applied to glass slides, and the number of eggs per suspension was determined using a 
light microscope. Worm fecundity was evaluated as the ratio between the number of eggs per gram of intestine and the number of adult worm pairs. One centimeter of the terminal ileum was obtained from each mouse, the fecal content was removed, and then the intestine was pressed between plastic slides. Approximately 100 eggs were evaluated with regard to their stage of embryonic development (Pellegrinot and Faria, 1965). The percentage of immature eggs from the first, second, third and fourth stages, as well as those of mature and dead eggs, was determined.

\section{Measurement of Hepatic Granuloma Area}

Fifty days post-infection, liver samples were taken from the central part of the left lateral lobe to assess granuloma formation. Liver samples were fixed in $4 \%$ formaldehyde in phosphate buffered saline (PBS), embedded in paraffin, and the histological sections obtained using microtome were stained with hematoxylin-eosin (HE). For the measurement of the hepatic granuloma area, images of all the granulomas in the exudative-productive stage (57-100 granulomas) for each group (5-10 granuloma from each mouse, 10-12 mice per group) were obtained using a camera attached to a light microscope (10 $\times$ objective lens). Only granulomas containing a single welldefined egg at the exudative-productive stage were selected from each liver section. The granuloma area $\left(\mu \mathrm{m}^{2}\right)$ was measured using the AxioVision version 4.8 image analysis software (Carl Zeiss MicroImaging GmbH, Germany).

\section{Granuloma Classification}

The developmental stages of S. mansoni granuloma formation were classified as previously described (Lenzi et al., 1998; Amaral et al., 2017). The following developmental stages of the granulomas were analyzed: exudative (E), the presence of an infiltrate of inflammatory cells in process of organization around the egg; exudative-productive (EP), characterized by organized infiltrate with circumferential aspect, showing a rich structure of collagen fibers and inflammatory cells concentrated in the periphery; and productive $(\mathrm{P})$, with a thick layer of collagen fibers between the egg and a reduced number of inflammatory cells. A total of 100 granulomas from the Ctrl group, and 80 granulomas from the LP $3 \%$ group, were recorded $(\sim 10$ granulomas per mouse).

\section{Biochemical Parameter Evaluation}

Hemoglobin, total protein and albumin levels were measured in blood samples taken from mice on the day (i) on which they initiated their experimental dietary regimen (day zero), (ii) before infection with S. mansoni (BI; 7 weeks after starting their experimental diets), and (iii) before perfusion (BP; 7 weeks after infection). Hemoglobin concentration was determined immediately after collection of blood samples using a commercial kit (Labtest Kit, Cat. 43, Lagoa Santa, MG, Brazil). Serum was separated by blood centrifugation, and total protein and albumin levels were determined using a commercial kit (Labtest Kit, Cat. 99 and 19, Lagoa Santa, MG, Brazil, respectively).

\section{Cytokine Analysis}

The cytokine profile induced by different experimental diets was assessed using serum samples obtained from mice on the day they initiated their experimental dietary regimen (day zero), before infection (BI) and before perfusion (BP), and in the liver samples at BP only. One hundred milligrams of liver were homogenized in $1 \mathrm{~mL}$ PBS containing an antiprotease cocktail (0.1 mM phenylmethylsulfonyl fluoride, $0.1 \mathrm{mM}$ benzethonium chloride, $10 \mathrm{mM}$ EDTA, and $20 \mathrm{KI}$ aprotinin A) and 0.05\% Tween 20. Samples were then centrifuged for $10 \mathrm{~min}$ at $3,000 \mathrm{~g}$ and cytokine levels were determined using $25 \mu \mathrm{L}$ of each supernatant. Cytokine measurement was performed using Cytometric Bead Array anti-mouse CBA Th1/Th2/Th17 Kit (BD Pharmingen, United States) according to the manufacturer's protocol. Data acquisition was performed using a FACSVerse flow cytometer (BD, United States), and analyzed using the FCAP Array Software (Becton Dickinson).

\section{Statistical Analysis}

GraphPad Prism 8.0 (Graph-Pad Software, San Diego, CA, United States) was used to perform the statistical analysis. Initially, the data were submitted to the Shapiro-Wilk normality test, followed by the Brown-Forsythe test to assess equality of variance. The results were analyzed using the non-parametric Mann-Whitney test, pair-by-pair, when the values of each group did not show equality of variance. In these cases, the alpha value was adjusted according to the number of comparisons made between the groups, and a 99\% confidence level was applied. When the values presented equality of variance, statistical analysis was performed using either one-way ANOVA or the Kruskal-Wallis test, followed by either Tukey or Dunn's multiple comparison tests, for parametric and non-parametric data, respectively. In these cases, a confidence level of 95\% was applied. GraphPad Prism 8.0, taking into account the entire family of comparisons, automatically adjusted the p values.

\section{RESULTS}

\section{Low Protein 3\% Diet Caused Malnutrition in Mice}

Body weight, concentration of hemoglobin in whole blood, and concentration of total protein and albumin in serum, were measured in animals from Control (Ctrl) and experimental groups (LP 3\% and LP 8\%, LF $2.5 \%$ and 5\%) to verify malnutrition status. One week after initiation of the experimental diets, LP 3\% mice exhibited significant decrease in body weight compared to Ctrl mice (Figure 1A). Significant differences in body weight were maintained between these two groups up to the end of the experimental period. In contrast, animals fed with other experimental diets showed no significant difference in body mass, in comparison to the Ctrl group. Seven weeks after initiation of the experimental diets, mice were infected with $\sim 100$ cercariae of $S$. mansoni, as indicated by the dashed line in Figure 1A. Body mass was not further changed by infection (Figure 1A). However, after infection, LP 3\%-fed mice showed 


\section{A}
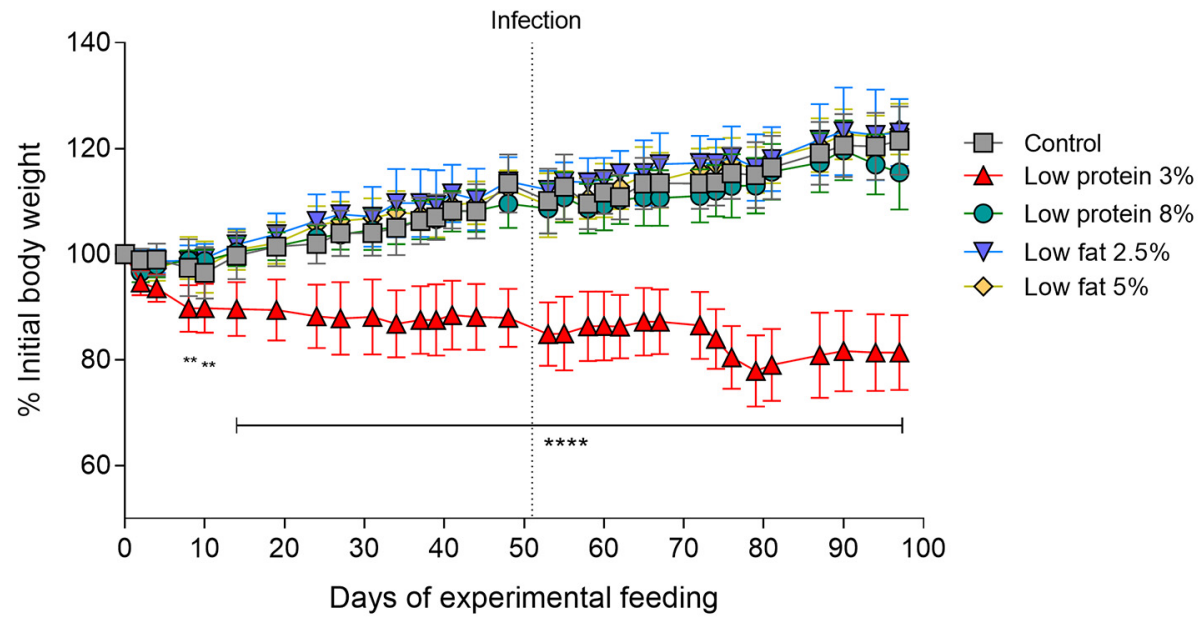

$\diamond \quad$ Low fat $5 \%$

B

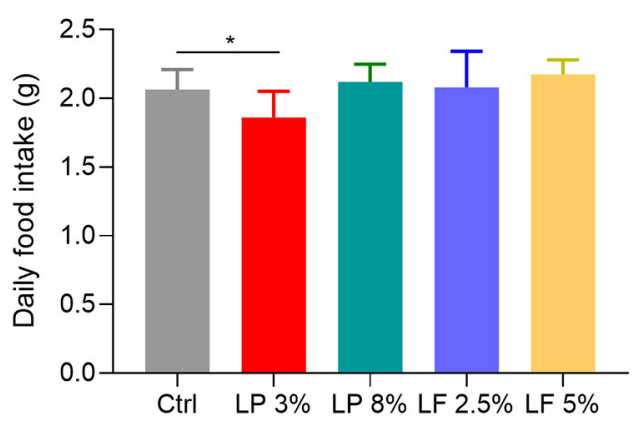

C

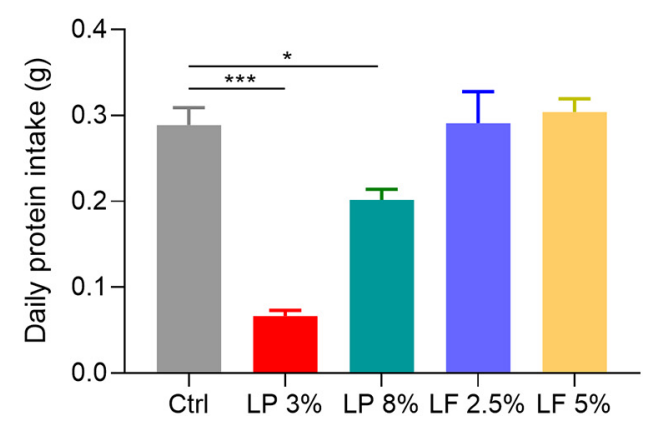

FIGURE 1 | Alterations in the body weight of mice fed with different experimental diets. Mice received different restricted diets: Control (Ctrl), Low protein 3 and $8 \%$ (LP 3\% and LP 8\%, respectively) and Low fat 2.5 and 5\% (LF 2.5\% and LF 5\%, respectively). Body weights (A) were measured three times a week. Dotted line indicates the time point when the mice were infected with $\sim 100$ cercariae of $S$. mansoni. Food (B) and protein intake (C) were measured daily, and are represented as per day/per mouse in grams. Values are presented as mean $\pm S D$ in each graph. Results are representative of two independent experiments $(n=12$ mice per group). Significant differences were determined by Two-way ANOVA followed by Tukey's multiple comparison test (A) or one-way ANOVA followed by Holm-Sidak's (B,C) $\left({ }^{\star} p \leq 0.05 ;{ }^{* \star} p \leq 0.01 ;{ }^{* \star *} p \leq 0.001 ;{ }^{* \star \star *} p \leq 0.0001\right)$.

reduced consumption of food (Figure 1B) and lower protein intake (Figure 1C), compared to the Ctrl group. LP 8\%-fed mice did not show any change in food intake, but presented a significant reduction in protein intake that reflects the protein deficiency of the diet. Furthermore, before infection, a significant reduction in albumin concentration was observed in LP 3\% mice (Figure 2). Significant differences were not observed before infection in total protein and hemoglobin levels among mice from the different experimental groups. However, infection with S. mansoni triggered a decrease in albumin, total protein and hemoglobin levels in LP 3\% mice compared to control mice, and in all groups when compared to the levels observed before infection (Figure 2). An additional experiment was performed including uninfected control groups (4 different groups of mice in total: uninfected Ctrl and LP 3\%, and infected Ctrl and LP 3\%), in order to evaluate whether the infection and/or the diet affect systemic levels of these biomarkers. Before infection, seventy days after initiating the experimental diet, both the uninfected and infected LP 3\% groups showed a significant reduction in the albumin concentration in relation to mice fed with the control diets (Supplementary Figure 1). The impact of the LP 3\% on the hemoglobin levels was observed 120 days after starting the diets. Lower levels of albumin and hemoglobin were observed in infected mice regardless of the diet. Infection only reduced total serum protein levels in LP 3\%-fed mice. These data demonstrate that the diet with $3 \%$ protein in its composition alone caused malnutrition in mice, which is then aggravated by infection with S. mansoni.

\section{Low Protein 3\% Diet Impacts S. mansoni Infection With Reductions in Eggs Trapped in the Liver and Parasite Fecundity}

In order to evaluate the impact of the different diets on S. mansoni infection, mice from all experimental groups were challenged with $\sim 100$ cercariae and the parasite burden was determined 50 days later. No differences were observed in the adult worm burden (Figure 3A) recovered, and in the number of eggs trapped in the liver, of mice fed with different experimental diets and 

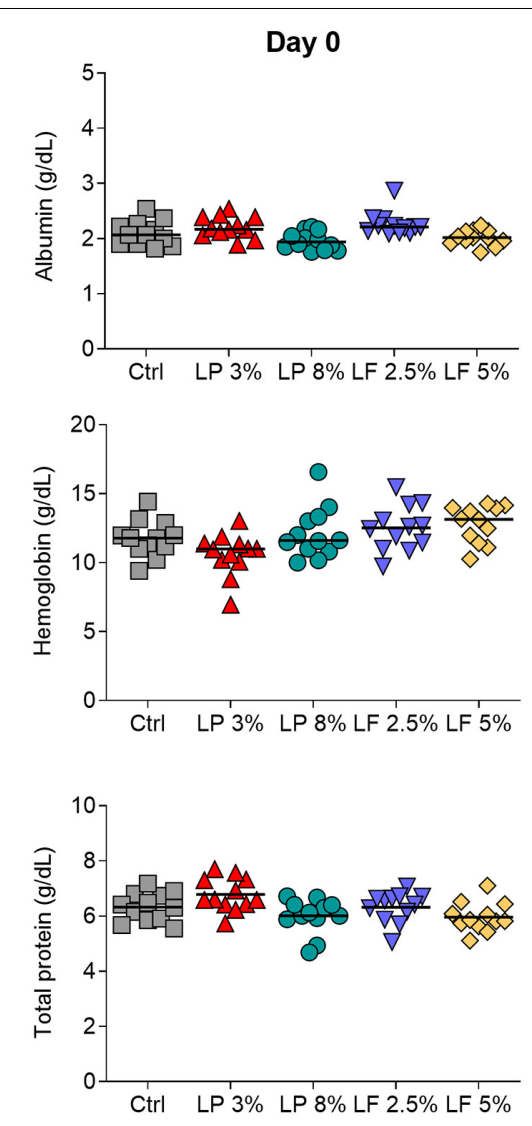
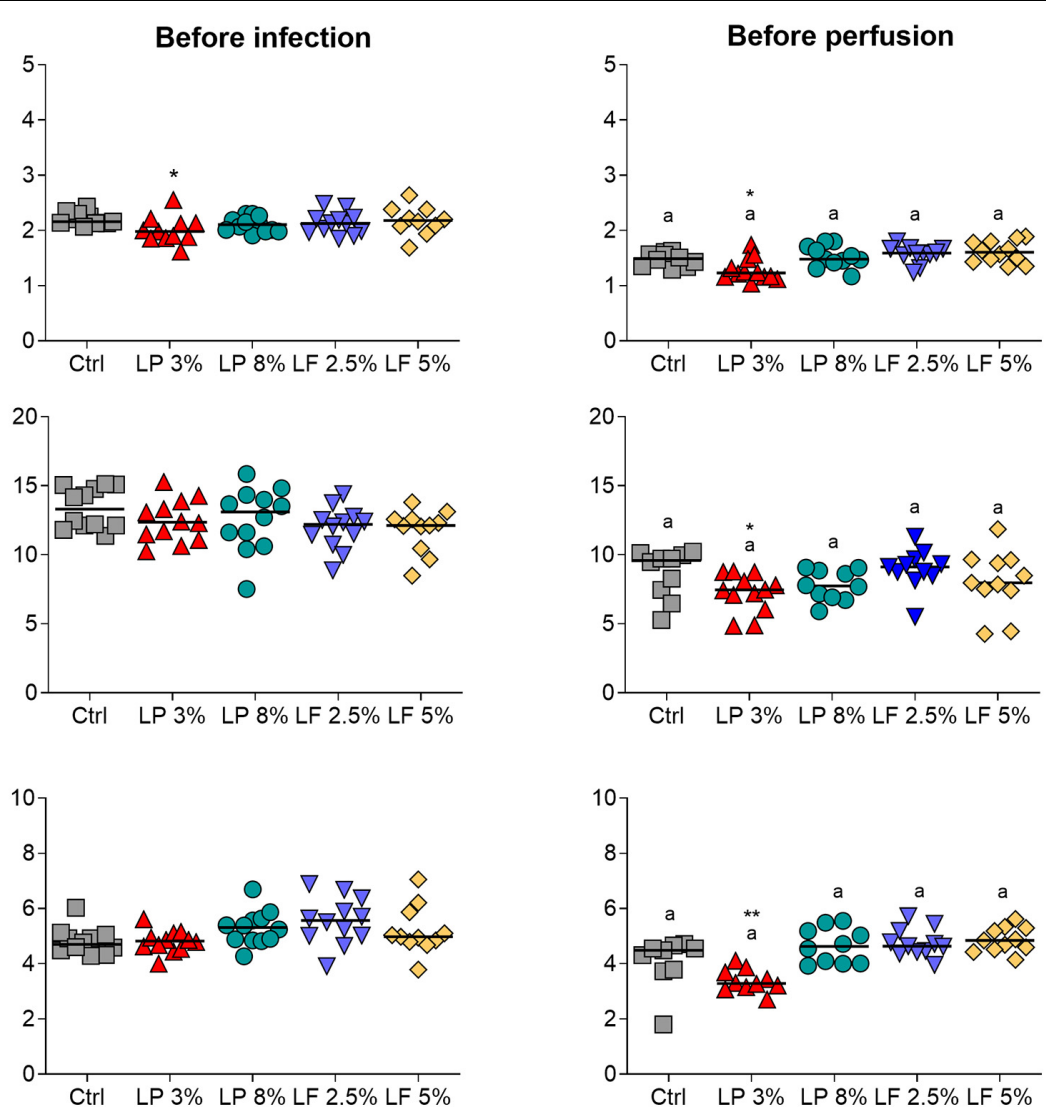

FIGURE 2 | Serum concentrations of albumin, hemoglobin and total protein in mice fed with different experimental diets. Mice received different restricted diets: Control (Ctrl), Low protein 3 and 8\% (LP 3\% and LP 8\%, respectively) and Low fat 2.5 and 5\% (LF 2.5\% and LF 5\%, respectively). Albumin, hemoglobin and total protein levels (from top to bottom) were measured on the first day of the experiment (day 0), before infection with $\sim 100$ cercariae of $S$. mansoni ( day 50 ) and before perfusion of the hepatic portal system ( $\sim$ day 100). The median is shown on each graph. Results are representative of two independent experiments $(n=10-12$ mice per group). Significant differences were determined by Kruskal-Wallis test followed by Dunn's multiple comparison test. "*” denote differences between LP $3 \%$ and Ctrl groups ( $\left.{ }^{*} p \leq 0.05 ;{ }^{* \star} p \leq 0.01\right)$; "a" denote differences between before infection and before perfusion in each group.

those from the control group (Figure 3B). However, the number of eggs trapped in the intestine was significantly lower in LP $3 \%$ mice than in control mice (Figure 3C). To assess whether this reduction occurred due to changes in parasite fecundity, the ratio between the number of eggs per gram of intestine and the number of adult worm pairs was calculated. As expected, LP 3\% mice exhibited a significant reduction in parasite fecundity in comparison to the control group (Figure 3D).

\section{Low Protein 3\% Diet Affects Liver Pathology Induced by S. mansoni Infection}

LP 3\% mice showed a significant reduction in the hepatic granuloma area in comparison the Ctrl group (Figures $4 \mathbf{A}, \mathbf{B}$ ). In order to explore the impact of malnutrition on granuloma development, we examined the developmental stages of hepatic granulomas. At 50 days after infection, the liver of the S. mansoni infected Ctrl and LP 3\% groups exhibited the expected occurrence of granulomas in different stages of maturation: Exudative (E), Exudative-productive (EP) and Productive (P).
However, LP 3\% mice showed an increase in the frequency of the E and decrease in the EP stages compared to the Ctrl group (Figures 4C,D). In order to assess whether S. mansoni egg maturation was impairing granuloma formation an oogram analysis was performed, but no significant difference in the percentage of the eggs in different maturation stages was observed between Ctrl and LP 3\% groups (Figure 4E).

\section{Cytokine Levels Triggered by S. mansoni Were Affected by Nutrient Composition of the Diet}

The levels of circulating cytokines in serum from the mice of all experimental groups were determined on day zero (before starting the experimental diets) (Supplementary Figure 2), before S. mansoni infection (BI) and before perfusion (BP) (Figure 5). Levels of cytokines were similar among groups at all time points evaluated (Supplementary Figure 2 and Figure 5). The levels of IL-2, IL-4, IL10, and IL-17 were also not significantly altered by infection (Figures 5D-G). Regardless of the diet, increased levels of IFN- $\gamma$ and IL- 6 were observed in mice BP 
A

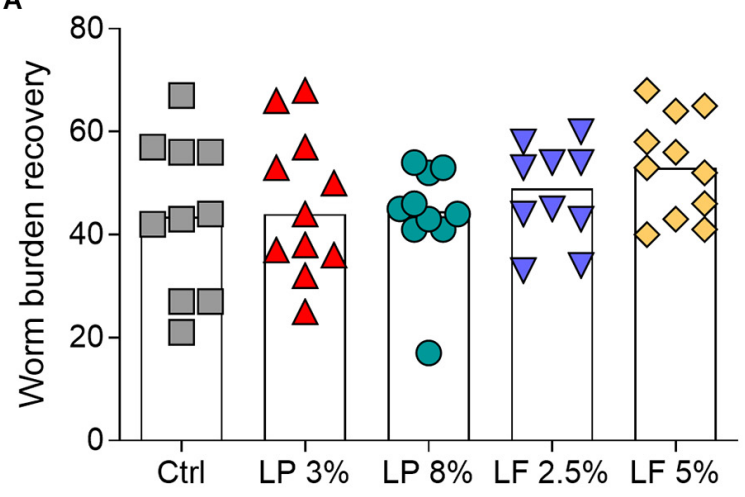

B

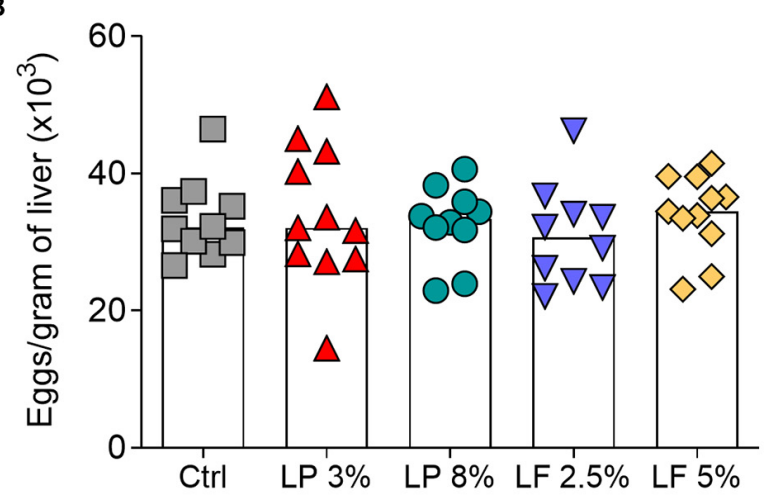

C

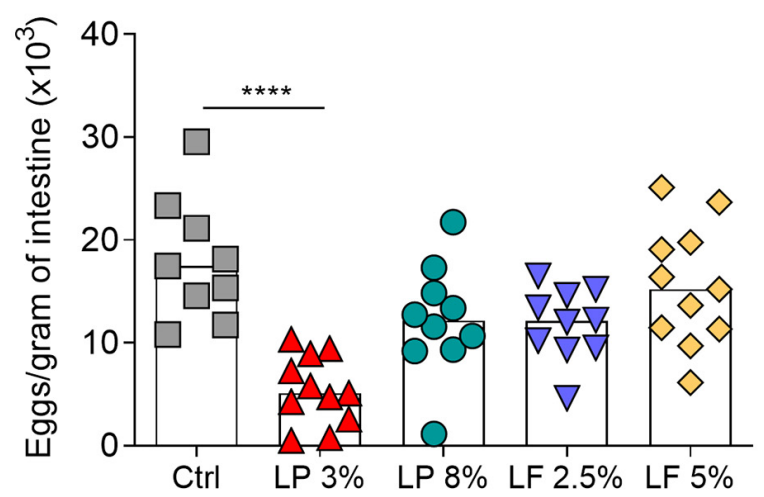

D

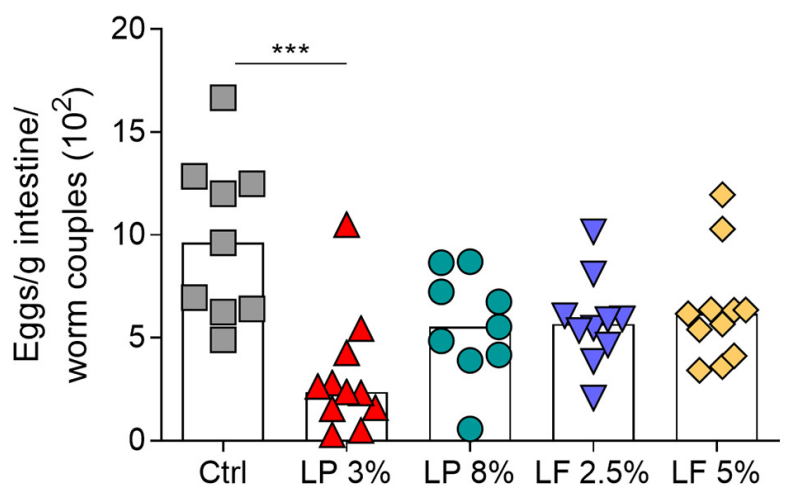

FIGURE 3 | Parasitological parameters of mice fed with different experimental diets. Mice received different restricted diets: Control (Ctrl), Low protein 3 and $8 \%$ (LP $3 \%$ and LP $8 \%$, respectively) and Low fat 2.5 and $5 \%$ (LF 2.5\% and LF 5\%, respectively). Adult worms were recovered approximately 50 days post-infection (A). The numbers of eggs per gram of liver (B) and intestine (C) were determined by optical microscopy after digestion of both tissues with $10 \% \mathrm{KOH}$. Fecundity was determined by the ratio between the number of eggs per gram of intestine and the number $S$. mansoni couples recovered by perfusion (D). Bars represent the median number of worms recovered or eggs per gram of organ. Results are representative of two independent experiments ( $n=10-12$ mice per group). Significant differences were determined by Kruskal-Wallis test followed by Dunn's multiple comparison test $\left({ }^{\star \star *} p \leq 0.001 ;{ }^{* \star * *} p \leq 0.0001\right)$.

when compared to BI (Figures 5A,C). On the other hand, induction of TNF upon infection was observed in Ctrl and LP $8 \%$ animals, but the same was not noticed in LP 3\%-fed mice (Figure 5B). In addition, LP 3\% mice showed decreased levels of cytokines IL- 4 and IFN- $\gamma$ in liver homogenate 50 days after infection by S. mansoni compared to the Ctrl group (Figure 6).

\section{DISCUSSION}

The relationship between nutrition, specifically protein deficiency, and infections has been evaluated previously (Magalhães et al., 1986; Rezende et al., 1997a; Anstead et al., 2003; Taylor et al., 2013; Losada-Barragán et al., 2019). However, the impact of malnutrition on susceptibility to $S$. mansoni infection is not well understood. In this study, we established a murine model of malnutrition to study the impact of this condition on experimental S. mansoni infection. We used diets with restricted protein (3 or $8 \%$ ) or lipid (2.5 or $5 \%$ ) content based on the formulations proposed by American Institute of Nutrition (AIN) (Reeves et al., 1993). AIN formulations are widely used in a variety of studies with different types of approaches (Malafaia et al., 2009; Lemes et al., 2016; Souza et al., 2020). These formulations provide researchers a definition for maintaining consistency between studies, as well as enabling specific individual nutrient adjustment to meet different goals (Pellizzon and Ricci, 2020).

In our model, we employed the most widely used protein concentration range $(2-8 \%)(12,23,24)$. Mice fed with LP 3\% diet, in contrast to those fed with LP $8 \%$, exhibited weight loss and, therefore, malnutrition. Data published by others demonstrate malnutrition even in mice fed with diets containing $8 \%$ protein. The different outcome observed in our study can be attributed to differences in the food composition, as previous studies used more restricted diets with multi-deficiency in macronutrients (mainly proteins and lipids), as well as minerals and vitamins (Teodósio et al., 1990; Coutinho et al., 1992; Rezende et al., 1997a; Barros et al., 2014; Santos et al., 2020).

As previously reported, in our study, besides presenting weight loss, animals fed with the LP 3\% diet consumed less food, and, therefore, less protein than control mice (Borelli et al., 2007; Fock et al., 2010). Possible mechanisms related to anorexia may 


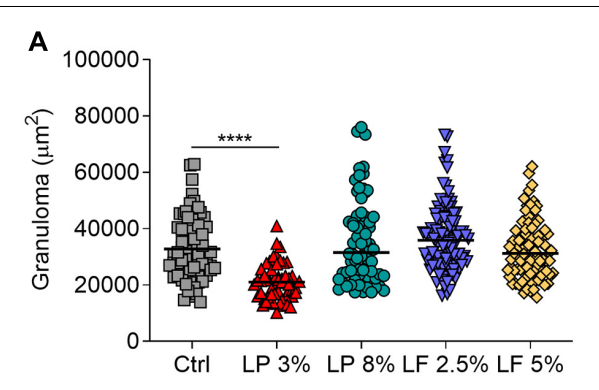

C

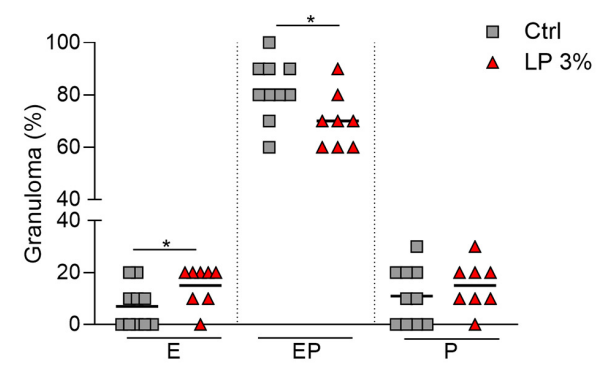

E

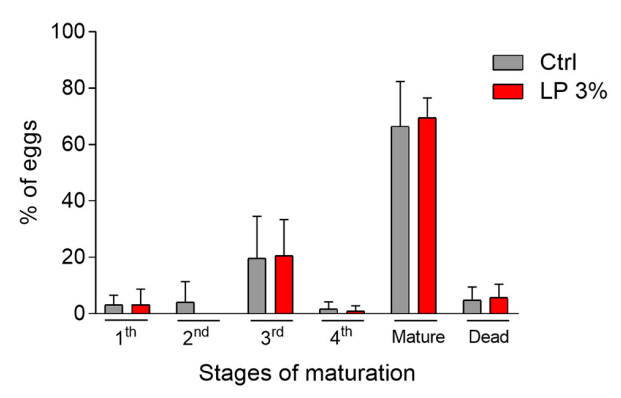

B
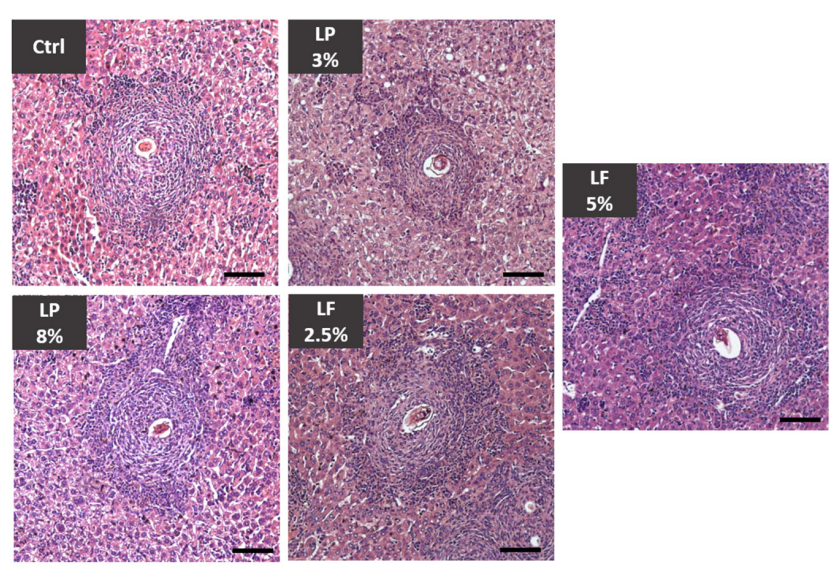

D
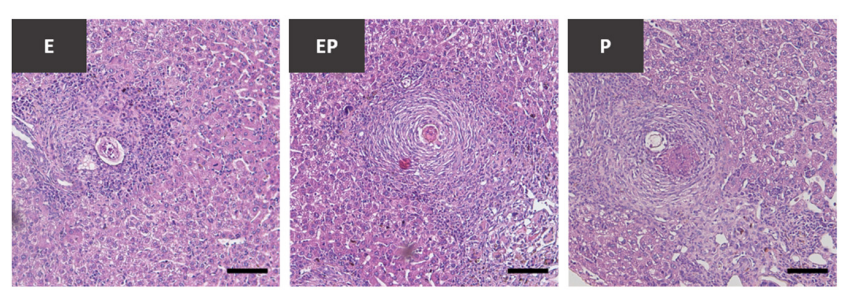

FIGURE 4 | Hepatic granuloma area in mice fed with different experimental diets. Mice received different restricted diets: Control (Ctrl), Low protein 3 and $8 \%$ (LP $3 \%$ and LP 8\%, respectively) and Low fat 2.5 and $5 \%$ (LF 2.5\% and LF 5\%, respectively). At 50 days post-infection, sections of liver from each mouse were obtained and slides were prepared and stained with hematoxyline-eosine. Approximately 100 granulomas containing a single well-defined egg at the exudative-productive stage were randomly selected and measured from the livers of mice from each experimental group. The total area of the granulomas was expressed in square micrometers $\left(\mu \mathrm{m}^{2}\right)$ and represented as the median (A). Representative histological sections of liver granulomas from each experimental group (B). Frequencies of granulomas in Ctrl and LP 3\% groups (C) and representative types of granulomas: E, exudative; EP, exudative-productive; P, productive (D). Percentage of S. mansoni eggs in different stages of development in the ileum: immature (first, second, third or fourth stages), mature and dead (E). Results are representative of two independent experiments ( $n=10-12$ mice per group). Significant differences were determined by Kruskal-Wallis test followed by Dunn's multiple comparison test (A), Student's $t$-tests $\mathbf{( C )}$ or Two-way ANOVA followed by Sidak's multiple comparison test $\mathbf{( E )}\left({ }^{*} p \leq 0.05 ;{ }^{* \star * *} p \leq 0.0001\right)$. Scale bar $=100 \mu m(100 x)$.

be explained by hypothalamic modifications or alterations in the serum concentration of branched amino acids, which may modulate the effects of neurotransmitters, leading to a possible adaptive process in order to prevent important changes in nitrogen balance (Gietzen, 1993; Fock et al., 2007).

In addition, mice fed with the LP 3\% diet showed a significant reduction in serum albumin levels in the period before infection and in all biochemical biomarkers assessed before perfusion. Although there are many factors that influence levels of serum proteins in plasma (Cabrerizo et al., 2015), albumin, hemoglobin and total protein are commonly used as biochemical indicators of the nutritional status (Barros et al., 2014; Nakajima et al., 2014; Oliveira et al., 2014; Santos et al., 2016; Zhang et al., 2017). Serum proteins, such as albumin, are characterized as negative acute-phase proteins, and their levels are affected by a number of inflammatory illnesses, mainly those associated with liver function (Fleck, 1989; Bharadwaj et al., 2016). Thus, in our model, both malnutrition and infection by $S$. mansoni affected serum albumin levels. Another parameter altered by the infection of animals fed with the LP 3\% diet was the hemoglobin concentration. Among the possible mechanisms responsible for the anemia reported in hosts infected by parasites of the genus Schistosoma, the most common cause is iron deficiency due to extra-corporeal loss (elimination of gastrointestinal blood and feces) (Mahmood, 1966; Farid et al., 1967), splenic sequestration (Mahmoud and Woodruff, 1973; Friis et al., 2003) or anemia developing upon inflammation (Mwatha et al., 1998; Abdel-Aaty et al., 1999; Means, 2000). It is worth mentioning that long periods of LP 3\% diet also decrease the levels of hemoglobin. Together, these data demonstrate that only the LP 3\% diet was able to induce malnutrition in mice characterized by the decrease in body mass, serum albumin, 

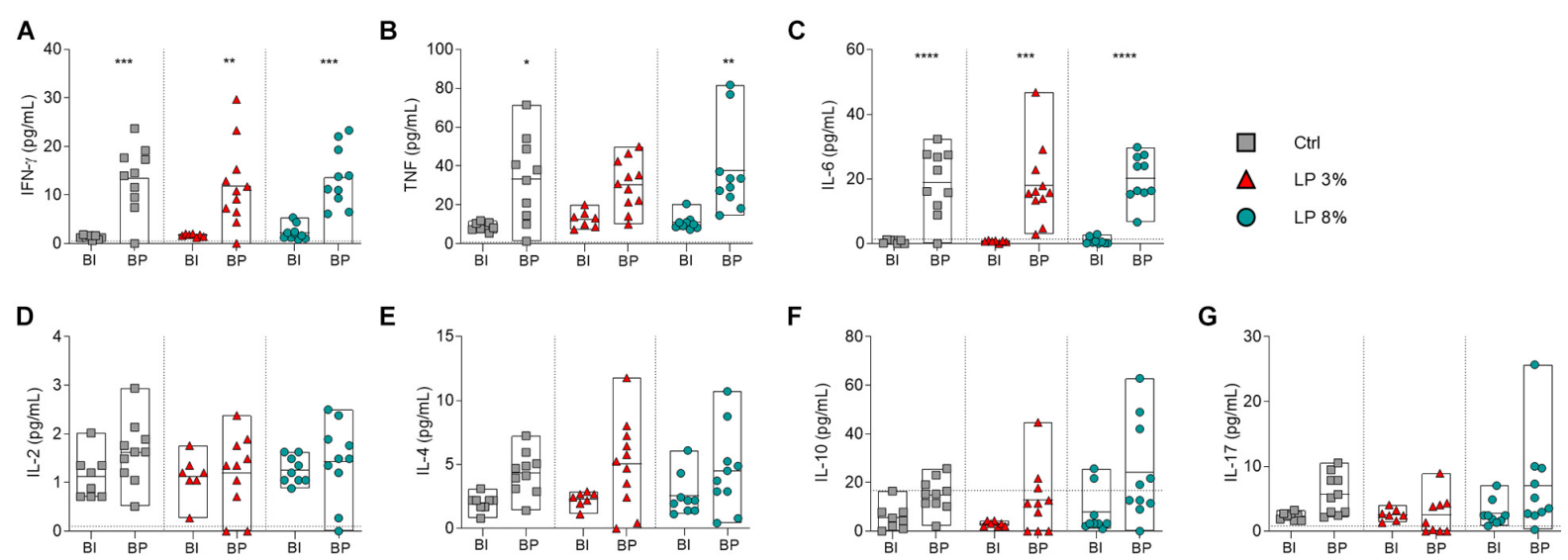

FIGURE 5 | Cytokine profile of mice fed with different experimental diets. Mice received different restricted diets: Control (Ctrl), Low protein 3 and $8 \%$ (LP $3 \%$ and LP $8 \%$, respectively). Serum samples were obtained before infection ( day 50), and before perfusion ( day 100) for cytokine measurement. Levels of IFN- $\gamma$ (A), TNF (B), IL-6 (C), IL-2 (D), IL-4 (E), IL-10 (F), and IL-17 (G) production were measured using the CBA Th1/Th2/Th17 kit. BI: before infection; BP: before perfusion. Results are representative of two independent experiments ( $n=6-11$ mice per group) and significant differences were determined by one-way ANOVA followed by Holm-Sidak's multiple comparison test $\left({ }^{*} p \leq 0.05 ;{ }^{* \star} p \leq 0.01 ;{ }^{* \star *} p \leq 0.001 ;{ }^{* \star \star *} p \leq 0.0001\right)$.
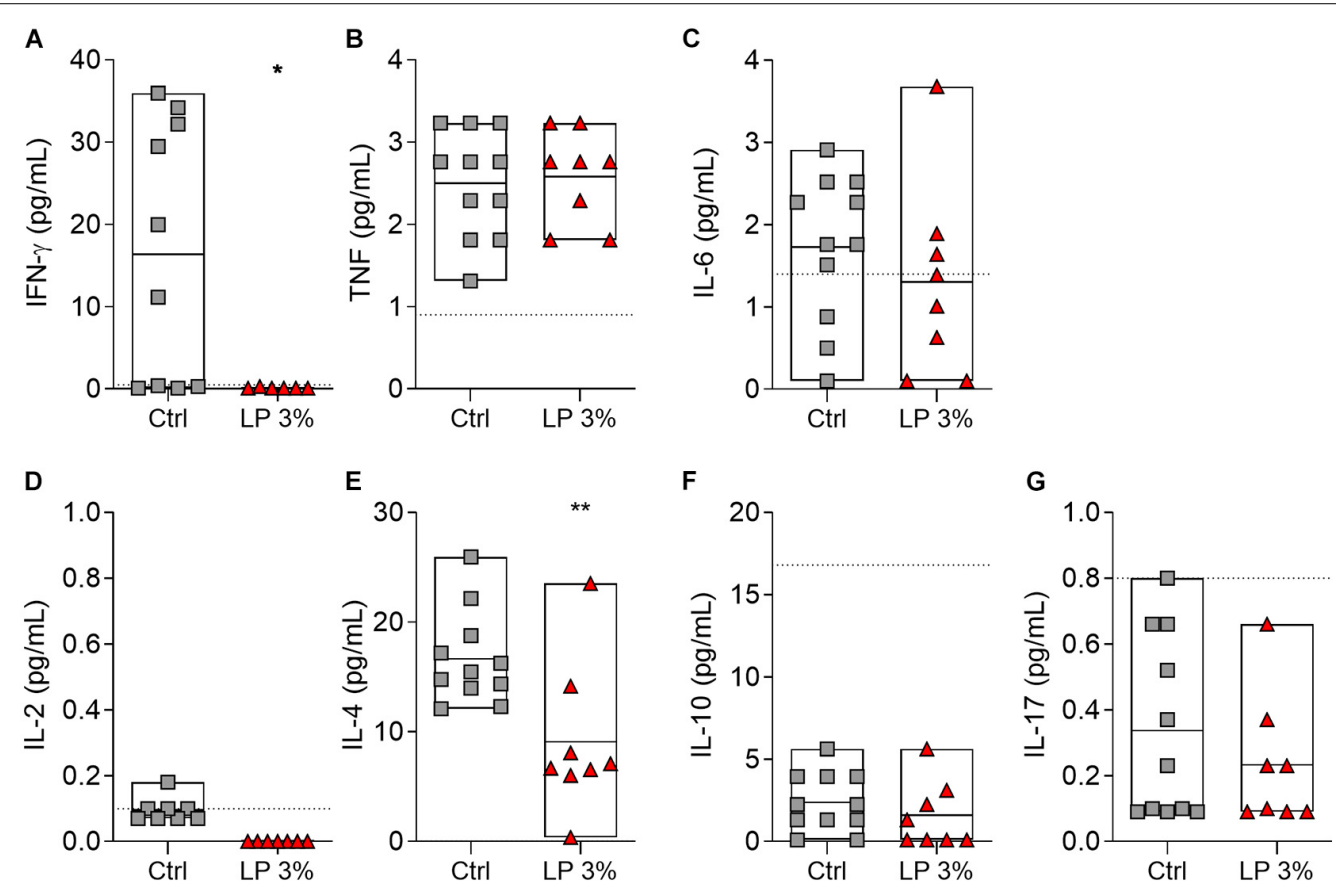

FIGURE 6 | Cytokine profile in the liver of mice fed with different experimental diets. Mice received Control (Ctrl) or Low protein 3\% (LP 3\%) diet and liver homogenates were obtained 50 days after infection (before perfusion) for cytokine measurement. Levels of IFN- $\gamma$ (A), TNF (B), IL-6 (C), IL-2 (D), IL-4 (E), IL-10 (F), and IL-17 (G) were measured using the CBA Th1/Th2/Th17 kit, $n=8-11$ mice per group. Significant differences were determined by Student's $t$-tests or Mann-Whitney test $\left({ }^{\star} p \leq 0.05 ;{ }^{* *} p \leq 0.01\right)$.

hemoglobin levels and food consumption, all indicators of a nutritional deficiency.

Previous studies have demonstrated the impact of host malnutrition on the biology and differentiation of S. mansoni, inducing phenotypic modifications in adult worms of both sexes (Neves et al., 2002; Oliveira et al., 2003). We did not find a significant difference in the number of adult worms recovered in malnourished animals compared to controls. However, there is no consensus in the literature regarding the impact of malnutrition on the establishment of infection (Simões et al., 2002; Coutinho et al., 2007; Barros et al., 2014). These divergences may be due to experimental approaches, such as mouse lineage, diet compositions and/or time of infection. 
Mice fed with LP 3\% diet have lower numbers of eggs trapped in the intestine. A high metabolism appears to be necessary for an adequate oogenesis by $S$. mansoni adult females (Davies et al., 2001). In this regard, animals fed with LP 3\% showed a reduction in parasite fecundity, but no impact on egg maturation. Morphological alterations of the schistosome reproductive system may explain the lower oviposition of worms recovered from malnourished experimental hosts (Oliveira et al., 2003; Blank et al., 2006). Moreover, these changes have been attributed to the reduced availability of essential nutrients necessary for adequate growth and development of the parasite in the blood vessels (Neves et al., 2002). Parasite growth and development are also dependent on immune factors (Amiri et al., 1992; Davies et al., 2001; Blank et al., 2006). TNF is required for oviposition in vivo and in vitro (Amiri et al., 1992). Our data showed that at day 50 of infection with S. mansoni increased circulating IFN- $\gamma$, IL- 6 and TNF levels were observed in mice with adequate nutritional status. In contrast, mice fed with LP 3\% diet did not display increased production of TNF after S. mansoni infection, suggesting that the different cytokine profile observed in malnourished mice in response to $S$. mansoni infection influence oviposition. However, further experiments are necessary to clarify the mechanisms responsible for the reduced parasite fecundity observed in these mice.

In our study, mice fed with low fat diets showed no changes in adult worm burden and in the number of eggs trapped in tissues. Previous studies have shown that $S$. mansoni cannot synthesize lipids de novo, and, therefore, the incorporation by the parasites of lipids from their environment is intense (Meyer et al., 1970; Brouwers et al., 1997). In vitro experiments have shown that several classes of lipids are incorporated more-or-less efficiently by adult worms, and there is interconversion from one class of lipid to another (Rumjanek and Simpson, 1980). Furthermore, the absence of fatty acid and cholesterol synthesis by $S$. mansoni indicate that there are efficient mechanisms for capturing host lipids (Rumjanek et al., 1988). In fact, when exposed to human serum, the parasites increase the expression of lipoprotein (LDL) receptors on the surface of their tegument (Rumjanek et al., 1988; Xu and Caulfield, 1992).

Hepatic granulomas are dynamic structures that show variable morphology depending on several factors, such as immune cells, cytokine patterns (Silva et al., 2000) and host nutritional status (Coutinho et al., 2007; Rezende et al., 1997a). Previous investigations on the relationships between schistosomiasis and host nutritional status have demonstrated that mice infected by $S$. mansoni and fed with a low-protein diet develop, in the acute phase of the disease, smaller peri-ovular granulomas with reduced hepatic collagen deposition (Coutinho et al., 2007; Barros et al., 2014).

Studies assessing the pathogenesis of schistosomiasis demonstrate the role of $\mathrm{CD} 4^{+} \mathrm{T}$ cells in the formation of hepatic granulomas. The Th1 response triggered by schistosomula and adult worm antigens play a role in the initial stage of granuloma formation (Pearce and MacDonald, 2002; Wynn et al., 2004; Wilson et al., 2007). IFN- $\gamma$ is important in the protective mechanism against hepatic fibrosis, while TNF can aggravate the pathogenesis (Henri et al., 2002; Booth et al., 2004), due to its roles in activating hepatic stellate cells and collagen deposition (Pradere et al., 2013; Yang and Seki, 2015). Th2 cytokines also have an important role in fibrogenesis, as demonstrated by the fact that mice deficient in STAT6 have granulomas with smaller area and less collagen content (Kaplan et al., 1998). Furthermore, IL-4 and IL-13 promote the differentiation of alternatively activated macrophages, which are known to enhance collagen production through an arginase-1-dependent mechanism (Hesse et al., 2001). On the other hand, IL-10 has a regulatory role in schistosomiasis, preventing the development of excessive pathologies mediated by both Th1 and Th2 responses (Hoffmann et al., 2000).

At the tissue level, LP 3\% mice show significantly reduced levels of IFN- $\gamma$ and IL-4 in the liver. Moreover, LP 3\% mice had smaller granulomas when compared with the Ctrl group. Studies demonstrated that in the absence of IFN- $\gamma$ signaling and Th2 cytokines smaller hepatic granulomas are observed during S. mansoni infection (Rezende et al., 1997b; Kaplan et al., 1998; Jankovid et al., 1999). Thus, the reduced levels of these cytokines could have influenced granuloma size in malnourished mice. Additionally, TNF and IL-13 have been associated with fibrosis (Tarrats et al., 2012; Schwartz et al., 2014). Our data showed no increase in circulating TNF levels in LP 3\% mice upon infection, and, although we have not measured IL-13 levels, studies demonstrated that the level of this cytokine is lower in the absence of IL-4 (Cheever et al., 1994). Our data also showed, for the first time, a delay in granuloma development due to nutritional status, in which in the livers of LP 3\%-fed mice there is an increased percentage of granulomas in the exudative phase and a decreased percentage in the exudativeproductive phase. This delay in the granuloma development, and their reduced area, observed in the LP 3\% mice, cannot be attributed to an impairment of egg maturation. However, further studies are still needed to investigate if protein-deficient diets impact the expression and secretion of egg antigens, such as IPSE and Omega-1 (Schramm et al., 2007; Everts et al., 2009), which are described to be involved in driving the Th2 response.

Overall, our results demonstrate that the 3\% low-protein diet was able to establish malnutrition in mice that influenced the outcome of experimental S. mansoni infection, reducing egg burden in the intestine, parasite fecundity and granuloma size. Additionally, malnutrition leads to a delay in granuloma development. These parameters may be associated with the cytokine milieu found in the liver. The establishment of this murine malnutrition model will enable future studies aiming to better understand the complex relationship between malnutrition, infection, and immunity. Additionally, this model could be used to test the effectiveness of any vaccine against diseases which affect populations living with food insecurity.

\section{DATA AVAILABILITY STATEMENT}

The original contributions presented in the study are included in the article/Supplementary Material, further inquiries can be directed to the corresponding author/s. 


\section{ETHICS STATEMENT}

The animal study was reviewed and approved by the Ethics Committee of Animal Use of FIOCRUZ. Licence number: LW2/18.

\section{AUTHOR CONTRIBUTIONS}

CF, LA, and PM designed the research, performed the data analysis, and wrote the manuscript. CF, LA, PM, and RG performed the experiments and discussed the data. All authors contributed to the article and approved the submitted version.

\section{FUNDING}

This study was financed in part by the Coordination for the Improvement of Higher Education Personnel (Coordenação de Aperfeiçoamento de Pessoal de Nível Superior-CAPES) Finance Code 001, Conselho Nacional de Desenvolvimento Científico e Tecnológico-Brasil (Grant Nos. 303131/2018-7 and 303152/2019-2), Instituto René Rachou - Fiocruz-MG, Programa CAPES/Print/Fiocruz and Rede De Pesquisa em Doenças Infecciosas Humanas e Animais do Estado de Minas

\section{REFERENCES}

Abdel-Aaty, H. E., Selim, M. M., and Abdel-Rehim, H. A. (1999). Study of gammainterferon in schistosomiasis mansoni, autoimmune diseases and schistosomal arthropathy. J. Egypt. Soc. Parasitol. 29, 721-734.

Amaral, K. B., Silva, T. P., Dias, F. F., Malta, K. K., Rosa, F. M., Costa-Neto, S. F., et al. (2017). Histological assessment of granulomas in natural and experimental Schistosoma mansoni infections using whole slide imaging. PLoS One 12, 1-20. doi: 10.1371/journal.pone.0184696

Amiri, P., Locksley, R. M., Parslow, T. G., Sadick, M., and Rector, E. (1992). Tumour necrosis factor alpha restores granulomas and induces parasite egglaying in schistosome-infected SCID mice. Nature 356, 604-607. doi: 10.1038/ $356604 \mathrm{a} 0$

Anstead, G. M., Chandrasekar, B., Zhang, Q., and Melby, P. C. (2003). Multinutrient undernutrition dysregulates the resident macrophage proinflammatory cytokine network, nuclear factor-kappa B activation, and nitric oxide production. J. Leukoc. Biol 74, 982-991. doi: 10.1189/jlb.0203064

Anstead, G. M., Chandrasekar, B., Zhao, W., Yang, J., Perez, L. E., and Melby, P. C. (2001). Malnutrition alters the innate immune response and increases early visceralization following Leishmania donovani infection. Infect. Immun. 69, 4709-4718. doi: 10.1128/IAI.69.8.4709-4718.2001

Atinmo, T., Mirmiran, P., Oyewole, O. E., Belahsen, R., and Serra-Majem, L. (2009). Breaking the poverty/malnutrition cycle in Africa and the Middle East. Nutr. Rev 67, S40-S46. doi: 10.1111/j.1753-4887.2009.00158.x

Bapat, P. R., Satav, A. R., Husain, A. A., Shekhawat, S. D., Kawle, A. P., Chu, J. J., et al. (2015). Differential levels of alpha-2-macroglobulin, haptoglobin and sero-transferrin as adjunct markers for TB diagnosis and disease progression in the malnourished tribal population of Melghat. India. PLoS One 10, 1-17. doi: 10.1371/journal.pone.0133928

Barros, A. F., Oliveira, S. A., Carvalho, C. L., Silva, F. L., de Souza, V. C. A., da Silva, A. L., et al. (2014). Low transformation growth factor- $\beta 1$ production and collagen synthesis correlate with the lack of hepatic periportal fibrosis development in undernourished mice infected with Schistosoma mansoni. Mem. Inst. Oswaldo Cruz 109, 210-219. doi: 10.1590/0074-0276140266
Gerais - FAPEMIG (RED00313-16). Fellowships: Capes (PM); $\mathrm{Pq}-\mathrm{CNPq}$ (CF and LA).

\section{ACKNOWLEDGMENTS}

We acknowledge the Program for Technological Development in Tools for Health-PDTIS-FIOCRUZ for the use of its Flow Cytometry and Microscopy and Image Microanalysis facilities. We thank the Lobato Paraense Mollusk facility at IRR for providing the S. mansoni cercariae and the Animal Facilities of the IRR for the provision and maintenance of experimental animals. We thank the IRR's project support service for project management and the GIPB Research group for the use of its laboratory infrastructure. We thank Sueleny Silva Ferreira Teixeira, Patrícia Martins Parreiras, Gardênia Braz Figueiredo de Carvalho, and Rafaela Donadoni de Souza for their assistance with the experiments, and Luara Isabela dos Santos for scientific discussions and technical help.

\section{SUPPLEMENTARY MATERIAL}

The Supplementary Material for this article can be found online at: https://www.frontiersin.org/articles/10.3389/fmicb. 2021.635843/full\#supplementary-material

Bharadwaj, S., Ginoya, S., Tandon, P., Gohel, T. D., Guirguis, J., Vallabh, H., et al. (2016). Malnutrition: Laboratory markers vs nutritional assessment. Gastroenterol. Rep. 4, 272-280. doi: 10.1093/gastro/gow013

Blank, R. B., Lamb, E. W., Tocheva, A. A., Crow, E. T., Lim, K. C., McKerrow, J. H., et al. (2006). The Common $\gamma$ Chain Cytokines Interleukin (IL)-2 and IL7 Indirectly Modulate Blood Fluke Development via Effects on CD4+ T Cells. J. Infect. Dis. 194, 1609-1616. doi: 10.1086/508896

Booth, M., Mwatha, J. K., Joseph, S., Jones, F. M., Kadzo, H., Ireri, E., et al. (2004). Periportal fibrosis in human Schistosoma mansoni infection is associated with low IL-10, kow IFN- $\gamma$, high TNF- $\alpha$, or low RANTES, depending on age and gender. J. Immunol. 172, 1295-1303. doi: 10.4049/jimmunol.172.2.1295

Borelli, P., Blatt, S., Pereira, J., de Maurino, B. B., Tsujita, M., de Souza, A. C., et al. (2007). Reduction of erythroid progenitors in protein-energy malnutrition. $\mathrm{Br}$. J. Nutr. 97, 307-314. doi: 10.1017/S0007114507172731

Brouwers, J. F. H. M., Smeenk, I. M. B., Van Golde, L. M. G., and Tielens, A. G. M. (1997). The incorporation, modification and turnover of fatty acids in adult Schistosoma mansoni. Mol. Biochem. Parasitol. 88, 175-185. doi: 10.1016/S01666851(97)00091-1

Cabrerizo, S., Cuadras, D., Gomez-Busto, F., Artaza-Artabe, I., Marín-Ciancas, F., and Malafarina, V. (2015). Serum albumin and health in older people: Review and meta analysis. Maturitas 81, 17-27. doi: 10.1016/j.maturitas.2015. 02.009

Cheever, A. W., Williams, M. E., Wynn, T. A., Finkelman, F. D., Seder, R. A., Cox, T. M., et al. (1994). Anti-IL-4 treatment of Schistosoma mansoni-infected mice inhibits development of T cells and non-B, non-T cells expressing Th2 cytokines while decreasing egg-induced hepatic fibrosis. J. Immunol. 153, 753-759.

Colley, D. G., Bustinduy, A. L., Secor, W. E., and King, C. H. (2014). Human schistosomiasis. Lancet 383, 2253-2264. doi: 10.1016/S0140-6736(13)61949-2

Coutinho, E. M., Abath, F. G. C., Barbosa, C. S., Domingues, A. L. C., Melo, M. C. V., Montenegro, S. M. L., et al. (1997). Factors Involved in Schistosoma mansoni Infection in Rural Areas of Northeast Brazil. Mem. Inst. Oswaldo Cruz 92, 707-715. doi: 10.1590/S0074-02761997000500027

Coutinho, E. M., de Freitas, L. P., and Abath, F. G. (1992). The influence of the regional basic diet from northeast Brazil on health and nutritional conditions of 
mice infected with Schistosoma mansoni. Rev. Soc. Bras. Med. Trop 25, 13-20. doi: 10.1590/S0037-86821992000100003

Coutinho, E. M., de Oliveira, S. A., de Barros, A. F., Silva, F. L., and Ramos, R. P. (2010). Manson's schistosomiasis in the undernourished mouse: Some recent findings. Memorias Do Inst. Oswaldo Cruz 105, 359-366. doi: 10.1590/S007402762010000400002

Coutinho, E. M., Silva, F. L., Barros, A. F., and Ara, R. E. (2007). Repeated infections with Schistosoma mansoni and liver fibrosis in undernourished mice. Acta Trop. 101, 15-24. doi: 10.1016/j.actatropica.2006.03.006

Davies, S. J., Grogan, J. L., Blank, R. B., Lim, K. C., Locksley, R. M., and McKerrow, J. H. (2001). Modulation of blood fluke development in the liver by hepatic CD4+ lymphocytes. Science 294, 1358x-1361x. doi: 10.1126/science.1064462

Everts, B., Perona-Wright, G., Smits, H. H., Hokke, C. H., Van Der Ham, A. J., Fitzsimmons, C. M., et al. (2009). Omega-1, a glycoprotein secreted by Schistosoma mansoni eggs, drives Th2 responses. J. Exp. Med. 206, 1673-1680. doi: 10.1084 /jem. 20082460

FAO (2019). The State of food security and nutrition in the world. Available online sat: http://www.fao.org/3/ca5162en/ca5162en.pdf [accessed August 10, 2020]

Farid, Z., Bassily, S., Schulert, A. R., Raasch, F., Zeind, A. S., Rooby, A. S. E. L., et al. (1967). Blood loss in chronic Schistosoma mansoni infection in Egyptian farmers. Trans. R. Soc. Trop. Med. Hyg. 61, 621-625. doi: 10.1016/00359203(67)90124- 1

Fleck, A. (1989). Clinical and nutritional aspects of changes in acute-phase proteins during inflammation. Proc. Nutr. Soc. 48, 347-354. doi: 10.1079/pns19890050

Fock, R. A., Blatt, S. L., Beutler, B., Pereira, J., Tsujita, M., de Barros, F. E. V., et al. (2010). Study of lymphocyte subpopulations in bone marrow in a model of protein-energy malnutrition. Nutrition 26, 1021-1028. doi: 10.1016/j.nut.2009. 08.026

Fock, R. A., Vinolo, M. A. R., Crisma, A. R., Nakajima, K., Rogero, M. M., and Borelli, P. (2008). Protein-energy malnutrition modifies the production of interleukin-10 in response to lipopolysaccharide (LPS) in a murine model. J. Nutr. Sci. Vitaminol. 54, 371-377. doi: 10.3177/jnsv.54.371

Fock, R. A., Vinolo, M. A. R., de Moura Sá Rocha, V., de Sá Rocha, L. C., and Borelli, P. (2007). Protein-energy malnutrition decreases the expression of TLR-4/MD2 and CD14 receptors in peritoneal macrophages and reduces the synthesis of TNF- $\alpha$ in response to lipopolysaccharide (LPS) in mice. Cytokine 40, 105-114. doi: 10.1016/j.cyto.2007.08.007

Friis, H., Mwaniki, D., Omondi, B., Muniu, E., Thiong'o, F., Ouma, J., et al. (2003). Effects on haemoglobin of multi-micronutrient supplementation and multi-helminth chemotherapy: A randomized, controlled trial in Kenyan school children. Eur. J. Clin. Nutr. 57, 573-579. doi: 10.1038/sj.ejcn.160 1568

Gbd 2016 DALYs Collaborators, H. (2017). Global, regional, and national disability-adjusted life-years (DALYs) for 333 diseases and injuries and healthy life expectancy (HALE) for 195 countries and territories, 1990-2016: A systematic analysis for the Global Burden of Disease Study 2016. Lancet 390, 1260-1344. doi: 10.1016/S0140-6736(17)32130-X

Gietzen, D. W. (1993). Neural mechanisms in the responses to amino acid deficiency. J. Nutr. 123, 610-625. doi: 10.1093/jn/123.4.610

Gryseels, B., Polman, K., Clerinx, J., and Kestens, L. (2006). Human schistosomiasis. Lancet 368, 1106-1118. doi: 10.1016/S0140-6736(06)69440-3

Henri, S., Chevillard, C., Mergani, A., Paris, P., Gaudart, J., Camilla, C., et al. (2002). Cytokine regulation of periportal fibrosis in humans infected with Schistosoma mansoni: IFN- $\gamma$ Is associated with Protection Against fibrosis and TNF- $\alpha$ with aggravation of disease. J. Immunol. 169, 929-936. doi: 10.4049/jimmunol.169.2. 929

Hesse, M., Modolell, M., La Flamme, A. C., Schito, M., Fuentes, J. M., Cheever, A. W., et al. (2001). Differential Regulation of Nitric Oxide Synthase-2 and Arginase- 1 by Type 1/Type 2 Cytokines In Vivo: Granulomatous Pathology Is Shaped by the Pattern of 1-Arginine Metabolism. J. Immunol. 167, 6533-6544. doi: 10.4049/jimmunol.167.11.6533

Hoffmann, K. F., Cheever, A. W., and Wynn, T. A. I. L. - (2000). 10 and the Dangers of Immune Polarization: Excessive Type 1 and Type 2 Cytokine Responses Induce Distinct Forms of Lethal Immunopathology in Murine Schistosomiasis. J. Immunol. 164, 6406-6416. doi: 10.4049/jimmunol.164.12.6406

Jankovid, D., Kullberg, M. C., Noben-Trauth, N., Caspar, P., Ward, JjM, Cheever, A. W., et al. (1999). Schistosome-Infected IL-4 Receptor Knockout (KO) Mice, in Contrast to IL-4 KO Mice, Fail to Develop Granulomatous Pathology
While Maintaining the Same Lymphokine Expression Profile. J. Immunol. 163, 337-342.

Kaplan, M. H., Whitfield, J. R., Boros, D. L., and Grusby, M. J. (1998). Th2 cells are required for the Schistosoma mansoni egg-induced granulomatous response. J. Immunol. 160, 1850-1856.

Katona, P., and Katona-Apte, J. (2008). The interaction between nutrition and infection. Clin. Infect. Dis. 46, 1582-1588. doi: 10.1086/587658

Komatsu, W., Mawatari, K., Miura, Y., and Yagasaki, K. (2007). Restoration by dietary glutamine of reduced tumor necrosis factor production in a lowprotein-diet-fed rat model. Biosci. Biotechnol. Biochem. 71, 352-357. doi: 10. 1271/bbb.60271

Lemes, C. G., de, C., Tiago, B. G. A., da Silva, W., de Oliveira, M. B., da Costa, E. D., et al. (2016). The Association of Malnutrition and Chronic Stress Models Does Not Present Overlay Effects in Male Wistar Rats. Open Access J. Sci. Technol. 4, 1-12. doi: 10.11131/2016/101222

Lenzi, H. L., Kimmel, E., Schechtman, H., Pelajo-Machado, M., Romanha, W. S., Pacheco, R. G., et al. (1998). Histoarchitecture of Schistosomal Granuloma Development and Involution: Morphogenetic and Biomechanical Approaches. Memorias Do Inst. Oswaldo Cruz 93, 141-151. doi: 10.1590/S007402761998000700020

Losada-Barragán, M., Umaña-Pérez, A., Durães, J., Cuervo-Escobar, S., RodríguezVega, A., Ribeiro-Gomes, F. L., et al. (2019). Thymic microenvironment is modified by malnutrition and Leishmania infantum infection. Front. Cell Infect. Microbiol. 9, 1-19. doi: 10.3389/fcimb.2019.00252

Magalhães, L. A., Guaraldo, A. M., Zanotti-Magalhães, E. M., de Carvalho, J. F., Sgarbieri, V. C., and de Alcântara, F. G. (1986). Schistosomiasis mansoni in experimentally malnourished mice. Rev. Saúde Pública 20, 362-368. doi: 10. 1590/s0034-89101986000500005

Mahmood, A. (1966). Blood loss caused by helminthic infections. Trans. R. Soc. Trop. Med. Hyg. 60, 766-769. doi: 10.1016/0035-9203(66)90226-4

Mahmoud, A. A. F., and Woodruff, A. W. (1973). The contribution of adult worms to the development of anaemia in schistosomiasis. Trans. R. Soc. Trop. Med. Hyg. 67, 171-173. doi: 10.1016/0035-9203(73)90141-7

Malafaia, G., Serafim, T. D., Silva, M. E., Pedrosa, M. L., and Rezende, S. A. (2009). Protein-energy malnutrition decreases immune response to Leishmania chagasi vaccine in BALB/c mice. Parasite Immunol. 31, 41-49. doi: 10.1111/j.1365-3024. 2008.01069.x

McManus, D. P., Dunne, D. W., Sacko, M., Utzinger, J., Vennervald, B. J., and Zhou, X. N. (2018). Schistosomiasis. Nat. Rev. Dis. Prim. 4, 1-19. doi: 10.1038/ s41572-018-0013-8

Means, R. T. (2000). The anaemia of infection. Bailliere's Best Pract. Res. Clin. Haematol. 13, 151-162. doi: 10.1053/beha.1999.0065

Mekonnen, Z., Meka, S., Zeynudin, A., and Suleman, S. (2014). Schistosoma mansoni infection and undernutrition among school age children in Fincha'a sugar estate, rural part of West Ethiopia. BMC Res. 7, 1-8. doi: 10.1186/17560500-7-763

Meyer, F., Meyer, H., and Bueding, E. (1970). Lipid metabolism in the parasitic and free-living flatworms, Schistosoma mansoni and Dugesia dorotocephala. Biochim. Biophys. Acta 210, 257-266. doi: 10.1016/0005-2760(70)90170-0

Mwatha, J. K., Kimani, G., Kamau, T., Mbugua, G. G., Ouma, J. H., Mumo, J., et al. (1998). High levels of TNF, soluble TNF receptors, soluble ICAM-1, and IFN-gamma, but low levels of IL-5, are associated with hepatosplenic disease in human schistosomiasis mansoni. J. Immunol. 160, 1992-1999.

Nakajima, K., Crisma, A. R., Silva, G. B., Rogero, M. M., Fock, R. A., and Borelli, P. (2014). Malnutrition suppresses cell cycle progression of hematopoietic progenitor cells in mice via cyclin D1 down-regulation. Nutrition 30, 82-89. doi: 10.1016/j.nut.2013.05.029

Neves, R. H., De Oliveira, S. A., Machado-Silva, J. R., Coutinho, E., and Gomes, D. C. (2002). Phenotypic characterization of Schistosoma mansoni adult worms recovered from undernourished mice: A morphometric study focusing on the reproductive system. Rev. Soc. Bras. Med. Trop. 35, 405-407. doi: 10.1590/ S0037-86822002000400019

Oliveira, D., Hastreiter, A. A., Mello, A. S., de Oliveira Beltran, J. S., Oliveira Santos, E. W. C., Borelli, P., et al. (2014). The effects of protein malnutrition on the TNF-RI and NF- $\kappa$ B expression via the TNF- $\alpha$ signaling pathway. Cytokine 69, 218-225. doi: 10.1016/j.cyto.2014.06.004

Oliveira, S. A., Barbosa, A. A., Gomes, D. C., Machado-Silva, J. R., Barros, A. F., Neves, R. H., et al. (2003). Morphometric Study of Schistosoma mansoni Adult 
Worms Recovered from Undernourished Infected Mice. Mem. Inst. Oswaldo Cruz 98, 623-627. doi: 10.1590/S0074-02762003000500007

Papier, K., Williams, G. M., Luceres-Catubig, R., Ahmed, F., Olveda, R. M., McManus, D. P., et al. (2014). Childhood malnutrition and parasitic helminth interactions. Clin. Infect. Dis. 59, 234-243. doi: 10.1093/cid/ciu211

Parraga, I. M., Assis, A. M. O., Prado, M. S., Barreto, M. L., Reis, M. G., King, C. H., et al. (1996). Gender differences in growth of school-aged children with schistosomiasis and geohelminth infection. Am. J. Trop Med. Hyg. 55, 150-156. doi: 10.4269/ajtmh.1996.55.150

Pearce, E. J., and MacDonald, A. S. (2002). The immunobiology of schistosomiasis. Nat. Rev. Immunol. 2, 499-511. doi: 10.1038/nri843

Pellegrino, J., and Siqueira, A. F. (1956). for recovery of Schistosoma mansoni from experimentally infected guinea pigs. Rev. Bras. Malariol. Doenças. Trop 8, 589-597.

Pellegrinot, J., and Faria, J. (1965). The oogram method for the screening of drugs in Schistosomiasis mansoni. Am. J. Trop. Med. Hyg. 14, 363-369.

Pellizzon, M. (2016). Choice of laboratory animal diet influences intestinal health. Nat. Publ. Gr. 45, 238-239. doi: 10.1038/laban.1014

Pellizzon, M. A., and Ricci, M. R. (2020). Choice of laboratory rodent diet may confound data interpretation and reproducibility. Curr. Dev. Nutr. 4, 1-9. doi: $10.1093 / \mathrm{cdn} / \mathrm{nzaa} 031$

Pradere, J. P., Kluwe, J., De Minicis, S., Jiao, J. J., Gwak, G. Y., Dapito, D. H., et al. (2013). Hepatic macrophages but not dendritic cells contribute to liver fibrosis by promoting the survival of activated hepatic stellate cells in mice. Hepatology 58, 1-17. doi: 10.1002/hep.26429

Reeves, P. G., Nielsen, F. H., and Fahey, G. C. (1993). AIN-93 purified diets for laboratory rodents: final report of the American Institute of Nutrition ad hoc writing committee on the reformulation of the AIN-76A rodent diet. J. Nutr. 123, 1939-1951. doi: 10.1093/jn/123.11.1939

Rezende, S. A., Oliveira, V. R., Silva, A. M., Alves, J. B., and Reis, L. F. (1997a). Mice Lacking the Gamma Interferon Receptor Have an Impaired Granulomatous Reaction to Schistosoma mansoni Infection. Infect. Immun. 65, 3457-3461.

Rezende, S. A., Oliveira, V. R., Silva, A. M., Alves, J. B., Goes, A. M., and Reis, L. F. L. (1997b). Mice lacking the gamma interferon receptor have an impaired granulomatous reaction to Schistosoma mansoni infection. Infect. Immun. 65, 3457-3461. doi: 10.1128/iai.65.8.3457-3461.1997

Rodriguez-Morales, A. J., Bolivar-Mejía, A., Alarcón-Olave, C., and CalvoBetancourt, L. S. (2016). Nutrition and Infection in Encyclopedia of Food and Health. Amsterdam: Elsevier Ltd, 98-103. doi: 10.1016/B978-0-12-384947-2. 00491-8

Ross, A. G. P., Bartley, P. B., Sleigh, A. C., Olds, G. R., Li, Y., Williams, G. M., et al. (2002). Schistosomasis. N. Engl. J. Med. 346, 1212-1220. doi: 10.1056/ NEJMra012396

Rumjanek, F. D., and Simpson, A. J. G. (1980). The incorporation and utilization of radiolabelled lipids by adult Schistosoma mansoni in vitro. Mol. Biochem. Parasitol. 1, 31-44. doi: 10.1016/0166-6851(80)90039-0

Rumjanek, F. D., Campos, E. G., and Crocco Afonso, L. C. (1988). Evidence for the occurrence of LDL receptors in extracts of schistosomula of Schistosoma mansoni. Mol. Biochem. Parasitol. 28, 145-152. doi: 10.1016/0166-6851(88) 90062-X

Santos, G. G., Batool, S., Hastreiter, A., Sartori, T., Nogueira-Pedro, A., Borelli, P., et al. (2016). The influence of protein malnutrition on biological and immunomodulatory aspects of bone marrow mesenchymal stem cells. Clin. Nutr. 36, 1149-1157. doi: 10.1016/j.clnu.2016.08.005

Santos, M. J. S., Canuto, K. M., de Aquino, C. C., Martins, C. S., Brito, G. A. C., Pessoa, T. M. R. P., et al. (2020). A Brazilian regional basic diet-induced chronic malnutrition drives liver inflammation with higher apoa-i activity in C57BL6J mice. Brazilian J. Med. Biol. Res. 53, 1-9. doi: 10.1590/1414-431x2020 9031

Schramm, G., Mohrs, K., Wodrich, M., Doenhoff, M. J., Pearce, E. J., Haas, H., et al. (2007). Cutting Edge: IPSE/alpha-1, a Glycoprotein from Schistosoma mansoni Eggs, Induces IgE-Dependent, Antigen-Independent IL-4 Production by Murine Basophils In Vivo. J. Immunol. 178, 6023-6027. doi: 10.4049/ jimmunol.178.10.6023

Schwartz, C., Oeser, K., da Costa, C., Layland, L. E., and Voehringer, D. (2014). T Cell-Derived IL-4/IL-13 Protects Mice against Fatal Schistosoma mansoni Infection Independently of Basophils. J. Immunol. 193, 3590-3599. doi: 10. 4049/jimmunol.1401155

Silva, L. M., Fernandes, A. L. M., Barbosa, A., Oliveira, I. R., and Andrade, Z. A. (2000). Significance of Schistosomal Granuloma Modulation. Mem. Inst. Oswaldo Cruz 95, 353-361. doi: 10.1590/S0074-02762000000300010

Simões, C., Neves, R. H., De Andrade Barros, L., Brito, P. D., Cravo, C. O., De Moura, E. G., et al. (2002). Parasitological characteristics of Schistosoma mansoni infection in Swiss mice with underlying malnutrition. Mem. Inst. Oswaldo Cruz 97, 143-147. doi: 10.1590/S0074-02762002000900027

Smithers, S. R., and Terry, R. J. (1965). The infection of laboratory hosts with cercariae of Schistosoma mansoni and the recovery of the adult worms. Parasitology 55, 695-700. doi: 10.1017/S0031182000086248

Souza, D. M. S., Costa, G. P., Leite, A. L. J., Oliveira, D. S., Farias, S. E. B., Silva, C. A. M., et al. (2020). A high-fat diet exacerbates the course of experimental Trypanosoma cruzi infection that can be mitigated by treatment with Simvastatin. BioMed. Res. Int. 2020, 1-14. doi: 10.1155/2020/1230461

Stephenson, L. S. (1994). Helminth parasites, a major facotr in malnutrition. World Health Forum. 15, 169-172.

Tarrats, N., Moles, A., Morales, A., García-Ruiz, C., Fernández-Checa, J. C., and Marí, M. (2012). Critical role of tumor necrosis factor receptor 1, but not 2, in hepatic stellate cell proliferation, extracellular matrix remodeling, and liver fibrogenesis. HepatolCogy 54, 319-327. doi: 10.1002/hep.24388

Taylor, A. K., Cao, W., Vora, K. P., De La Cruz, J., Shieh, W. J., Zaki, S. R., et al. (2013). Protein energy malnutrition decreases immunity and increases susceptibility to influenza infection in mice. J. Infect. Dis. 207, 501-510. doi: 10.1093/infdis/jis527

Teodósio, N. R., Lago, E. S., Romani, S. A., and Guedes, R. C. A. (1990). regional basic diet from northeast Brazil as a dietary model of experimental malnutrition. Arch. Latinoam Nutr. 40, 533-547.

WHO (2020). Schistosomiasis. Key facts. Available online at: https://www.who.int/ news-room/fact-sheets/detail/schistosomiasis [accessed September 10, 2020]

Wilson, M. S., Mentink-Kane, M. M., Pesce, J. T., Ramalingam, T. R., Thompson, R., and Wynn, T. A. (2007). Immunopathology of schistosomiasis. Immunol. Cell Biol. 85, 148-154. doi: 10.1038/sj.icb.7100014

Wynn, T. A., Thompson, R. W., Cheever, A. W., and Mentink-Kane, M. M. (2004). Immunopathogenesis of schistosomiasis. Immunol. Rev. 201, 156-167. doi: $10.1111 / j .0105-2896.2004 .00176 . x$

Xu, X., and Caulfield, J. P. (1992). Characterization of human low density lipoprotein binding proteins on the surface of schistosomula of Schistosoma mansoni. Eur. J. Cell Biol. 57, 229-235.

Yang, Y. M., and Seki, E. (2015). TNFa in liver fibrosis. Phys. Behav. 3, 253-261. doi: 10.1007/s40139-015-0093-z

Zhang, Z., Pereira, S. L., Luo, M., and Matheson, E. M. (2017). Evaluation of blood biomarkers associated with risk of malnutrition in older adults: A systematic review and meta-analysis. Nutrients 9:nu9080829. doi: 10.3390/nu908 0829

Conflict of Interest: The authors declare that the research was conducted in the absence of any commercial or financial relationships that could be construed as a potential conflict of interest.

Copyright $\odot 2021$ Maciel, Gonçalves, Antonelli and Fonseca. This is an open-access article distributed under the terms of the Creative Commons Attribution License (CC BY). The use, distribution or reproduction in other forums is permitted, provided the original author(s) and the copyright owner(s) are credited and that the original publication in this journal is cited, in accordance with accepted academic practice. No use, distribution or reproduction is permitted which does not comply with these terms. 